\title{
Pengembangan Media Pembelajaran Fisika Interaktif Menggunakan Adobe Flash CS3 pada Konsep Induksi Elektomagnetik di SMA Negeri 9 Palu
}

\author{
Christison Luist David Horonis, Sahrul Saehana, dan I Wayan Darmadi \\ luistdavidhoronis@gmail.com \\ Program Studi Pendidikan Fisika FKIP Universitas Tadulako \\ Jl. Soekarno Hatta Km. 9 Kampus Bumi Tadulako Tondo Palu - Sulawesi Tengah
}

\begin{abstract}
Abstrak - Penelitian ini dilakukan dengan tujuan untuk mengembangkan dan mengetahui kualitas, kelayakan, dan keefektifan media pembelajaran fisika interaktif menggunakan adobe flash CS3 pada konsep induksi elektromagnetik. Penelitian ini merupakan jenis penelitian dan pengembangan yang mengacu pada desain pengembangan Borg and Gall. Subjek penelitian ini adalah peserta didik kelas XII IPA 1 (N=26) SMA Negeri 9 Palu. Pengumpulan data dilakukan dengan metode tes dan angket. Hasil analisis data validasi ahli materi menunjukkan skor rata-rata 3,65 (Sangat Baik), validasi ahli media menunjukkan skor rata-rata 3,82 (Sangat Baik), penilaian guru menunjukkan skor rata-rata 3,88 (Sangat Baik), dan respon peserta didik menunjukkan skor rata-rata 3,26 (Sangat Setuju). Uji coba penggunaan media pembelajaran menunjukkan peningkatan hasil belajar peserta didik dengan nilai rata-rata $N$-gain 0,47 (Sedang). Hasil penelitian ini menunjukkan bahwa media pembelajaran fisika interaktif menggunakan adobe flash CS3 pada konsep induksi elektromagnetik yang dikembangkan memiliki kelayakan dan efektif digunakan sebagai media pembelajaran.
\end{abstract}

Kata Kunci : media pembelajaran fisika interaktif, adobe flash CS3, induksi elektromagnetik

\section{PENDAHULUAN}

Pendidikan merupakan salah satu bagian yang penting dalam kehidupan manusia. Pendidikan salah satunya dapat dimaknai sebagai kumpulan segala macam proses seseorang mengembangkan kemampuan, sikap dan bentuk-bentuk tingkah laku lainnya yang bernilai positif di masyarakat tempat dia tinggal.

Pendidikan yang ada saat ini, menuntut adanya keaktifan dari peserta didik dengan cara membuat suasana belajar dan proses pembelajaran yang dapat menarik peserta didik untuk lebih cepat berpikir, merespon dan memahami suatu masalah dalam ruang lingkup pendidikan. Untuk menghasilkan peserta didik yang sesuai dengan tujuan yang diinginkan oleh Undang-undang, maka sekolah sebagai penyelenggara pendidikan harus meningkatkan dalam hal perbaikan dan perubahan di dalam seluruh komponen-komponen pendidikan [1].

Untuk mencapai tujuan pendidikan tentunya tidaklah mudah. Sebab terdapat beberapa kendala baik berupa sistem dan proses pembelajaran. Salah satunya guru sebagai tenaga pendidik masih banyak yang hanya memikirkan penguasaan konsep dan hanya melakukan proses pembelajaran yang masih konvensional [2]. Selain itu guru juga hanya mampu melakukan proses pembelajaran dengan metode ceramah, sebab sejak dulu metode ini telah digunakan sebagai alat komunikasi lisan antara guru sebagai tenaga pendidik dengan peseta didik.

Fisika merupakan salah satu pelajaran yang sangat penting karena membahas tentang fenomena fisis mengenai alam, ilmu yang mempelajari unsur dasar pembentukan alam semesta, gaya-gaya yang bekerja di dalamnya dan akibat-akibat yang ditimbulkannya [3]. Namun, Haeruddin [2] mengatakan bahwa Fisika merupakan salah satu pelajaran yang kurang diminati oleh peserta didik dan hal ini merupakan pendapat umum. Salah satu penyebabnya adalah fisika banyak mempunyai konsep-konsep yang bersifat abstrak. Fisika merupakan salah satu pelajaran yang tergolong abstrak sehingga peserta didik kesulitan dalam mempelajari dan memahami tentang gejala-gejala fisika yang tampak secara nyata maupun yang tidak.

Dalam fisika terdapat dua gejala yang dapat divisualisasikan yakni yang berkaitan dengan gerak dan yang tidak berkaitan dengan gerak. Contoh konsep fisika yang berkaitan dengan gerak yakni gelombang dan konsep fisika yang tidak berkaitan dengan gerak adalah gaya listrik, pola interferensi, difraksi, dan lain sebagainya. [3].

Seiring perkembangan zaman, teknologi mempunyai peranan yang penting dalam dunia pendidikan. Dengan adanya teknologi dalam dunia pendidikan akan memudahkan guru dan peserta didik untuk melakukan proses pembelajaran [3]. 
Teknologi multimedia merupakan pendukung dalam proses pembelajaran. Dengan adanya hal tersebut, diperlukan teknologi multimedia yang dapat membantu untuk memvisualisasikan konsep fisika [4]. Salah satunya adalah adobe flash CS3. Media ini dapat menunjang pembelajaran fisika karena dapat diwujudkan animasi yang sekiranya akan mendukung guru dalam menerapkan pembelajaran yang interaktif, sehingga peserta didik dapat dengan mudah memahami dan mengerti tentang konsep fisika dan nantinya peserta didik tidak hanya akan terpaku pada persamaan dan rumus-rumus yang ada.

Sebelum melakukan penelitian, peneliti melakukan observasi di SMA Negeri 9 Palu. Hasil observasi menunjukkan bahwa penggunaan media pembelajaran interaktif dalam mata pelajaran fisika masih jarang digunakan. Sehingga keefektifan pembelajaran masih sangat minim. Selain itu pembelajaran fisika cenderung terdapat pada waktu-waktu siang, sehingga membuat peserta didik tidak fokus pada pembelajaran. Oleh karena itu penelitian ini bertujuan untuk mengembangankan media pembelajaran interaktif pada salah satu materi fisika yakni induksi elektromagnetik guna memberikan pembelajaran yang lebih menarik, inspiratif, menyenangkan, kreatif dan dapat membangkitkan kemandirian peserta didik dalam melakukan proses pembelajaran.

\section{METODE PENELITIAN}

Jenis penelitian yang digunakan adalah penelitian dan pengembangan atau Research and Development ( $R$ \& D). Penelitian dan pengembangan adalah penelitian yang digunakan untuk menghasilkan produk tertentu dan menguji keefektifan produk tersebut [5]. Adapun dalam penelitian pengembangan media pembelajaran ini menggunakan langkah-langkah penelitian pengembangan yang dikemukakan oleh Borg and Gall [5]. Langkah-langkah penelitian tersebut dapat dilihat pada Gambar 1.

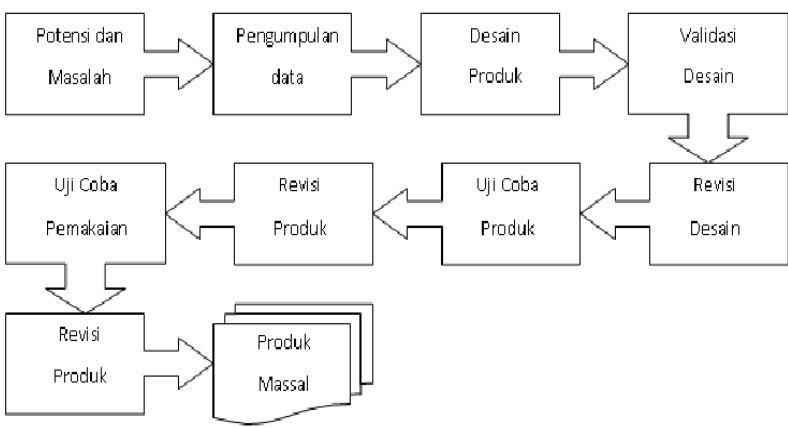

Gambar 1. Tahapan penggunaan metode research and development ( $R \& D$ ) menurut Borg and Gall
Pada penelitian ini tidak semua tahapan atau langkah-langkah akan digunakan. Penelitian ini hanya sampai pada uji coba produk. Uji coba produk yang dimaksud adalah uji coba produk dalam skala kecil. Hal ini disebabkan karena hasil penelitian ini tidak diproduksi secara masal dan uji coba yang dilakukan terbatas. Adapun langkah-langkah penelitian ini, yaitu:

1. Potensi dan Masalah

2. Pengumpulan Data

3. Desain Produk

4. Validasi Produk

5. Revisi Produk

6. Uji Coba Produk (Uji Coba terbatas dan Uji Coba Kelas)

7. Analisis dan Pelaporan

Subjek penelitian ini adalah 26 orang peserta didik kelas XII IPA 1 SMA Negeri 9 Palu. Hal ini dikarenakan media pembelajaran yang dikembangkan memuat isi materi induksi elektromagnetik yang diajarkan pada kelas XII IPA.

Teknik pengumpulan data yang digunakan dalam penelitian ini adalah tes dan angket. Tes yang digunakan adalah tes hasil belajar yang bertujuan untuk mengetahui peningkatan hasil belajar peserta didik selama menggunakan media pembelajaran yang dikembangkan. Tes yang diberikan adalah tes jenis pilihan ganda sebanyak 20 nomor untuk soal pretest dan posttest. Angket atau kuesioner yang diberikan kepada ahli media, ahli materi, guru pengampu mata pelajaran dan peserta didik sebagai respondennya. Angket atau kuesioner digunakan untuk menilai kualitas dan kelayakan dari media pembelajaran yang dihasilkan.

Teknik analisa data menggunakan analisis deskriptif yang memaparkan hasil pengembangan produk. Data yang diperoleh melalui angket dianalisis melalui perhitungan rata-rata yang didasarkan oleh pendapat dari Arikunto [6], yang menyatakan bahwa untuk mengetahui peringkat nilai akhir pada setiap butir angket penelitian, jumlah nilai yang diperoleh dibagi dengan banyaknya butir pertanyaan. Sehingga diperoleh rumus untuk menghitung nilai rata-rata adalah sebagai berikut.

$$
\bar{X}=\frac{\sum x}{n}
$$

Keterangan:

$\bar{X} \quad$ :nilai rata-rata dalam tiap butir pernyataan

$\sum x$ :jumlah nilai dari seluruh penilaian dalam tiap butir pernyataan

$n \quad$ :jumlah butir pernyataan 
Kemudian diolah dalam bentuk data kualitatif berdasarkan kriteria kategori penilaian dalam Tabel 1 dan 2 [7].

TABEL 1 KRITERIA PENILAIAN PRODUK

Interval Skor

$3,25<\bar{X} \leq 4,00$

$2,50<\bar{X} \leq 3,25$

$1,75<\bar{X} \leq 2,50$

$1,00 \leq \bar{X} \leq 1,75$

TABEL 2 KRITERIA KATEGORI RESPON PESERTA DIDIK

Interval Skor

Kategori

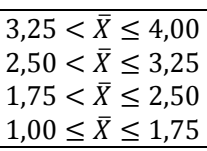

$3,25<\bar{X} \leq 4,00$

$2,50<\bar{X} \leq 3,25$

$1,75<\bar{X} \leq 2,50$

$1,00 \leq \bar{X} \leq 1,75$

Kategori

SB (Sangat Baik)
B (Baik)
K (Kurang)
SK (Sangat Kurang)

Data tes dianalisis dengan menghitung gain ternormalisasi ( $\mathrm{N}$-gain). Untuk mengitung ratarata $\mathrm{N}$-gain dengan menggunakan rumus [8]:

$$
\mathrm{g}=\frac{\mathrm{S}_{\text {post }} \mathrm{S}_{\mathrm{pre}}}{\mathrm{S}_{\mathrm{maks}} \mathrm{S}_{\mathrm{pre}}} \ldots \ldots .
$$

Keterangan :

g $=N$-gain

$S_{\text {post }}=$ skor post-test

Spre $\quad=$ skor pre-test

Smaks = skor maksimum tes

Dengan kriteria sebagai berikut :

$\begin{array}{lll}\mathrm{g} \geq & \mathrm{z}, 7 & =\text { Tinggi } \\ 0,3 \leq \mathrm{g}<0,7 & =\text { Sedang } \\ \mathrm{g}< & 0,3=\text { Rendah }\end{array}$

\section{HASIL DAN PEMBAHASAN}

\section{A. Hasil Penelitian}

Hasil penelitian pengembangan media pembelajaran ini disajikan dalam bentuk aplikasi flash dengan judul "Media Pembelajaran Fisika Interaktif Induksi Elektromagnetik". Adapun bagian-bagian dari media pembelajaran ini terdiri dari beberapa komponen yang diuraikan sebagai berikut.

1. Komponen Media Pembelajaran

1) Loading

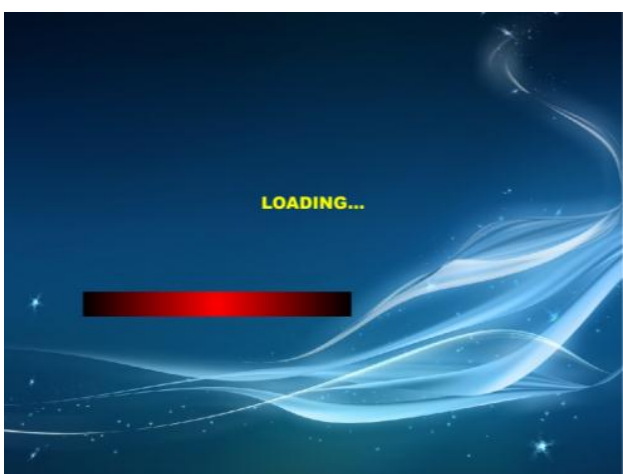

Gambar 2. Tampilan Loading

2) Form Login

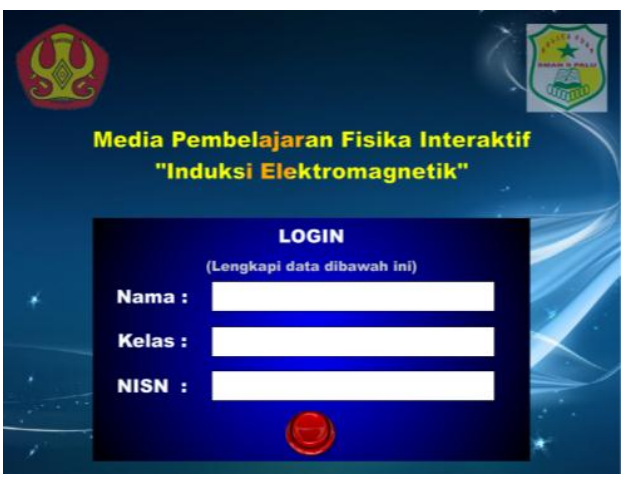

Gambar 3. Tampilan Login

3) Petunjuk Penggunaan

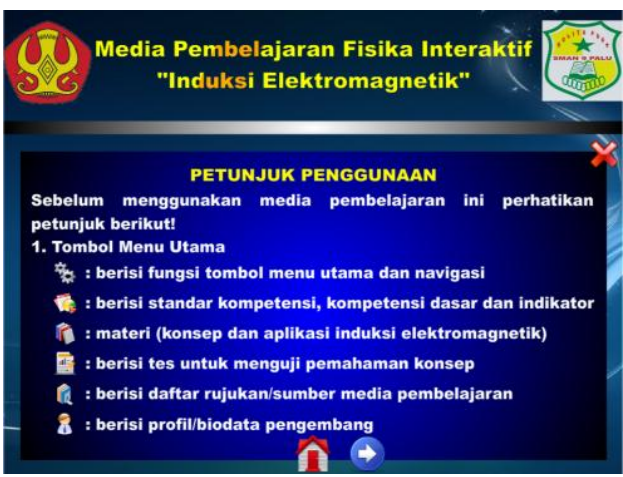

Gambar 4. Tampilan Petunjuk Penggunaan

4) Menu Utama

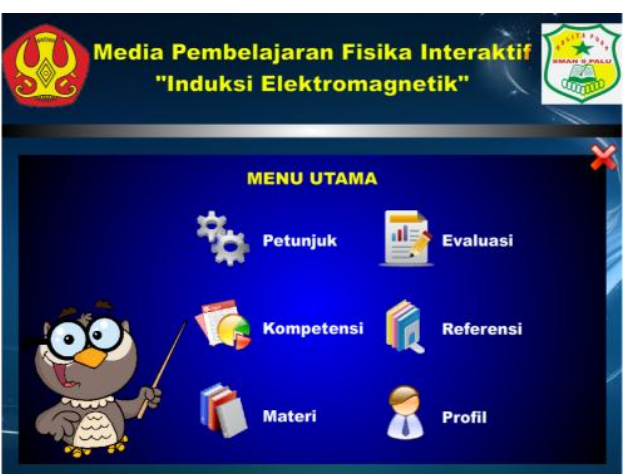

Gambar 5. Tampilan Menu Utama 
5) Kompetensi

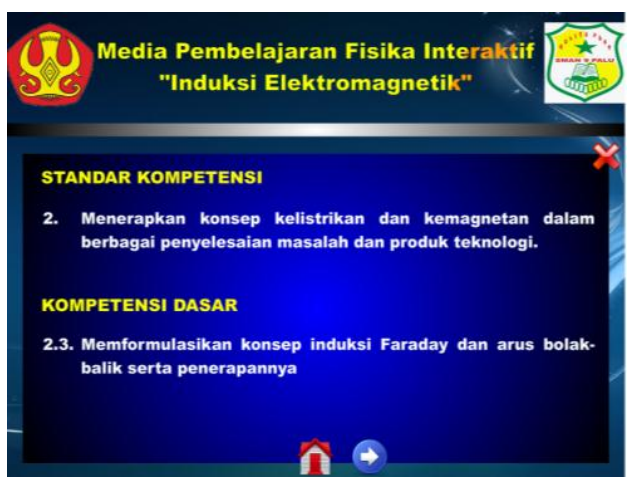

Gambar 6. Tampilan Kompetensi

6) Materi

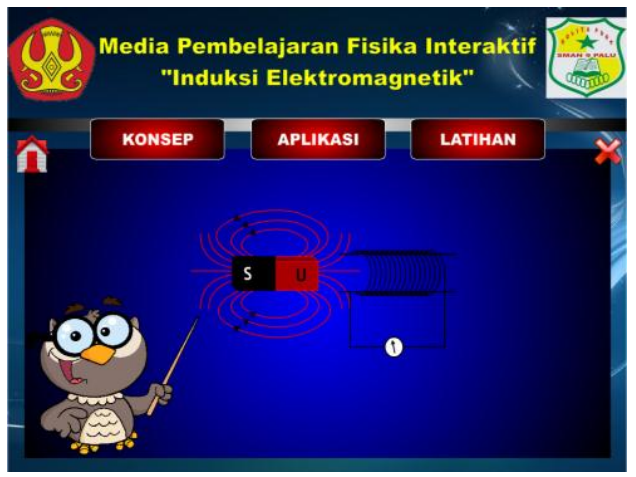

Gambar 7. Tampilan Materi

7) Evaluasi

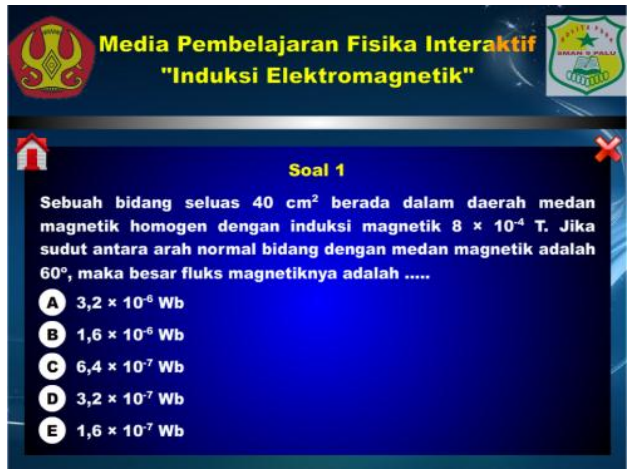

Gambar 8. Tampilan Evaluasi

8) Referensi

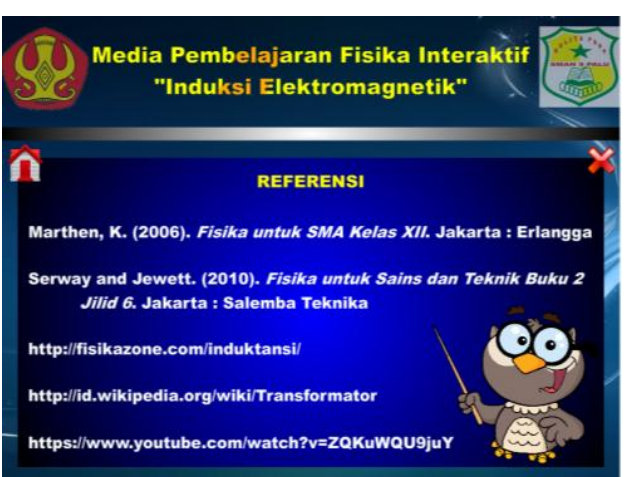

Gambar 9. Referensi

\section{9) Profil Pengembang}

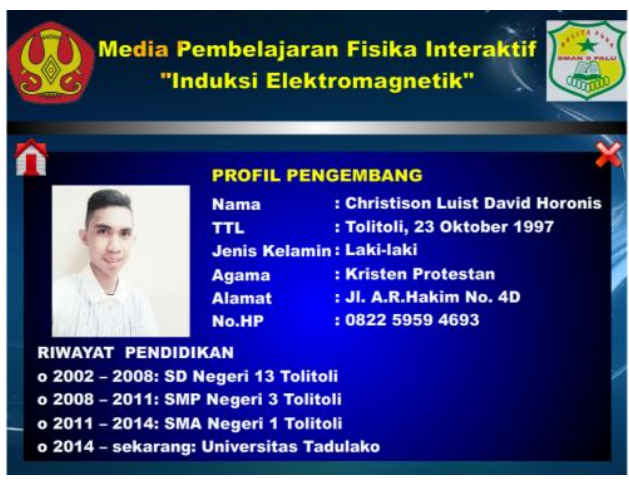

Gambar 10. Profil Pengembang

2. Validasi Produk

Hasil validasi oleh ahli materi terhadap media pembelajaran yang dihasilkan, menunjukkan skor rata-rata 3,65 dengan kategori "Sangat Baik". Validasi ahli materi meliputi aspek materi, aspek pembelajaran, dan aspek bahasa. Hasil ini menunjukkan bahwa media pembelajaran layak untuk digunakan dalam pembelajaran. Revisi dilakukan seperlunya dengan memperbaiki struktur penggunaan bahasa dalam media pembelajaran. Hasil validasi ahli materi dapat dilihat pada Tabel 3.

\begin{tabular}{cccc}
\multicolumn{5}{l}{ TABEL } & HASIL VALIDASI OLEH AHLI MATERI & \\
\hline No & Aspek & Skor & Kategori \\
\hline 1 & Materi & 3,65 & Sangat Baik \\
2 & Pembelajaran & 3,90 & Sangat Baik \\
3 & Bahasa & 3,40 & Sangat Baik \\
\hline & Rata-rata & 3,65 & Sangat Baik \\
\hline
\end{tabular}

Hasil validasi oleh ahli media terhadap media pembelajaran yang dihasilkan, menunjukkan skor rata-rata 3,82 dengan kategori "Sangat Baik". Validasi ahli media meliputi aspek pemrograman dan aspek tampilan. Hasil ini menunjukkan bahwa media pembelajaran layak untuk digunakan dalam pembelajaran. Revisi dilakukan seperlunya dengan menambahkan beberapa tombol navigasi untuk memudahkan pengguna pada bagian materi pembelajaran. 
Hasil validasi ahli media dapat dilihat pada Tabel 4.

TABEL 4 HASIL VALIDASI OLEH AHLI MEDIA

\begin{tabular}{cccc}
\hline No & Aspek & Skor & Kategori \\
\hline 1 & Pemrograman & 3,75 & Sangat Baik \\
2 & Tampilan & 3,88 & Sangat Baik \\
\hline & Rata-rata & 3,82 & Sangat Baik \\
\hline
\end{tabular}

Validasi produk dilakukan untuk mengukur kualitas dan kelayakan dari media pembelajaran yang dihasilkan dan dilakukan revisi apabila terdapat saran dan kritik dari validator. Validasi produk dilakukan oleh salah satu dosen pendidikan fisika sebagai ahli materi dan salah satu dosen pendidikan fisika sebagai ahli media.

Validasi isi materi dalam media pembelajaran dilakukan oleh validator ahli materi. Aspek yang dinilai dari media pembelajaran yang dihasilkan meliputi aspek materi, aspek pembelajaran, dan aspek bahasa. Rata-rata hasil penilaian pada aspek materi adalah 3,65 ; rata-rata hasil penilaian pada aspek pembelajaran adalah 3,90; dan rata-rata hasil penilaian pada aspek bahasa adalah 3,40. Skor rata-rata dari keseluruhan penilaian aspek oleh ahli materi adalah 3,65 dan dikategorikan "Sangat Baik". Dari hasil tersebut, validator ahli materi menyatakan bahwa media pembelajaran yang dihasilkan layak untuk di uji cobakan dengan revisi sesuai saran.

Validasi program dan tampilan dalam media pembelajaran dilakukan oleh validator ahli media. Aspek yang dinilai dari media pembelajaran yang dihasilkan meliputi aspek pemrograman dan aspek tampilan. Rata-rata hasil penilaian pada aspek pemrograman adalah 3,75 dan rata-rata hasil penilaian pada aspek tampilan adalah 3,88. Skor rata-rata dari keseluruhan penilaian aspek oleh ahli materi adalah 3,82 dan dikategorikan "Sangat Baik". Dari hasil tersebut, validator ahli media menyatakan bahwa media pembelajaran yang dihasilkan layak untuk di uji cobakan dengan revisi sesuai saran.

\section{Uji Coba Produk}

Hasil pengembangan media pembelajaran ini diujikan kepada 26 orang peserta didik di kelas XII IPA 1 SMA Negeri 9 Palu. Uji coba dilakukan dengan dua cara yakni uji coba terbatas untuk mengetahui respon tanggapan peserta didik terhadap media pembelajaran dan uji coba kelas dengan menggunakan media pembelajaran yang dihasilkan dalam proses pembelajaran untuk mengetahui keefektifan penggunaan media pembelajaran tersebut dilihat dari peningkatan hasil belajar peserta didik.
Uji coba terbatas dilakukan oleh peserta didik dengan melakukan pengisian angket respon peserta didik terhadap media pembelajaran yang dihasilkan. Angket tersebut memiliki 33 item pernyataan yang besifat postif dengan empat opsi atau pilihan, yaitu sangat setuju dengan skor 4, setuju dengan skor 3, tidak setuju dengan skor 2 dan sangat tidak setuju dengan skor 1 . Hasil uji coba terbatas terhadap peserta didik menunjukkan bahwa media pembelajaran yang dikembangkan layak digunakan sebagai media pembelajaran sesuai dengan tanggapan respon peserta didik yang menunjukkan skor rata-rata 3,26 dengan kategori "Sangat Setuju" terhadap media pembelajaran.

Uji coba terbatas juga dilakukan terhadap guru mata pelajaran fisika. Uji coba dilakukan untuk mengetahui penilaian kualitas media pembelajaran. Hasil uji coba terbatas terhadap guru mata pelajaran menunjukkan skor 3,88 dengan kategori "Sangat Baik". Selain itu, guru mata pelajaran fisika mengatakan bahwa penelitian mengenai pengembangan media pembelajaran ini menjadi masukan yang baik untuk sekolah khususnya mata pelajaran fisika dan guru mata pelajaran.

Uji coba kelas dilaksanakan dengan cara menerapkan media pembelajaran yang dihasilkan dalam proses pembelajaran. Uji coba dilaksanakan dengan eksperimen yakni dengan cara melihat peningkatan hasil belajar peserta didik terhadap materi yang diajarkan melalui media pembelajaran. Tes yang digunakan adalah tes hasil belajar yang sebelumnya telah divalidasi oleh validator ahli. Sebelum dilakukan pembelajaran, diberikan pretest untuk mengetahui kemampuan awal peserta didik sebelum diterapkannya penggunaan media pembelajaran tersebut. Hasil pretest menunjukkan nilai terendah 20 dan nilai tertinggi 70 . Setelah di terapkan penggunaan aplikasi media pembelajaran dalam proses pembelajaran, diberikan posttest untuk mengetahui hasil belajar dengan menggunakan media pembelajaran yang dihasilkan. Hasil posttest menunjukkan nilai terendah 40 dan nilai tertinggi 85. Dari hasil pretest dan posttest, dilakukan analisis untuk melihat peningkatan hasil belajar dengan melakukan uji $\mathrm{N}$-gain. Hasil $N$-gain dapat dilihat pada Tabel 5 .

\begin{tabular}{|c|c|c|c|}
\hline Subjek & $\begin{array}{l}\text { Nilai Rata- } \\
\text { rata Pre-Test }\end{array}$ & $\begin{array}{c}\text { Nilai Rata- } \\
\text { rata Post- } \\
\text { Test }\end{array}$ & $\begin{array}{c}\text { Nilai } N \text {-Gain } \\
\text { Rata-rata }\end{array}$ \\
\hline \multirow[t]{2}{*}{26} & 42,88 & 69,62 & 0,47 \\
\hline & Kategori & & Sedang \\
\hline
\end{tabular}




\section{B. Pembahasan}

Hasil penelitian ini menunjukkan bahwa aplikasi media pembelajaran yang telah dikembangkan menunjukkan kualitas sangat baik, layak digunakan sebagai media pembelajaran fisika dan memiliki keefektifan dalam penggunaannya yakni dalam meningkatkan hasil belajar peserta didik.

Aplikasi media pembelajaran yang telah dikembangkan memiliki ukuran 3,34 MB yang dikembangkan menggunakan aplikasi/ software adobe flash CS3 yang merupakan salah satu jenis aplikasi yang digunakan untuk membuat desain dan membangun perangkat presentase yang didukung dengan berbagai fitur yang menarik yakni pembuatan animasi, gambar, video, dan lain sebagainya. Aplikasi yang dihasilkan tergolong memiliki ukuran yang sangat kecil, sehingga dapat di tempatkan di mana saja pada bagian penyimpanan.

Aplikasi media pembelajaran ini dibuat dengan resolusi 800 × 600 pixel. Hal ini disesuaikan dengan ukuran tampilan standar apabila media pembelajaran ini digunakan dengan bantuan proyektor. Di dalam media pembelajaran ini dilengkapi dengan petunjuk penggunaan yang dapat memudahkan pengguna dalam menggunakannya, materi yang berisi penjelasan, gambar, animasi, video, contoh dan latihan soal. Selain itu, terdapat evaluasi yang dapat mengukur sejauh mana kemampuan pengguna dalam memahami meteri induksi elektromagnetik.

Hasil penelitian ini didukung oleh penelitian sebelumnya [4] yang menunjukkan bahwa media pembelajaran berbasis flash layak digunakan sebagai sumber belajar mandiri untuk peserta didik.

Aplikasi media pembelajaran fisika interaktif yang telah dikembangkan tentunya mempunyai kelebihan dan kekurangan. Adapun kelebihan dari aplikasi ini yakni mudah dalam pengoperasiannya karena disertai dengan petunjuk penggunaan, memiliki ukuran yang dapat digolongkan tidak terlalu besar, dalam materi pembelajaran terdapat gambar, animasi, serta video yang dapat mendukung dan merangsang peserta didik untuk mengetahui lebih jauh tentang materi yang disajikan dalam aplikasi tersebut. Selain itu aplikasi media pembelajaran tersebut dapat digunakan dimana saja dengan didukung oleh perangkat komputer dan aplikasi/software flash yang ter-instal dalam perangkat komputer tersebut.

Kekurangan aplikasi media pembelajaran ini yaitu belum terdapatnya simulasi dalam aplikasi media pembelajaran yang dapat mengembangkan pengetahuan, kreatifitas dan kemandirian dari peserta didik. Hal ini dikarenakan masih kurangnya pengetahuan dan keterampilan peneliti dalam penggunaan aplikasi/software adobe flash CS3 serta waktu uji coba produk yang sudah semakin dekat dikarenakan waktu uji coba produk disesuaikan dengan waktu materi pembelajaran.

\section{KESIMPULAN DAN SARAN}

\section{A. Kesimpulan}

Berdasarkan hasil penelitian dan pengembangan ini dapat disimpulkan bahwa telah dihasilkan media pembelajaran fisika interaktif menggunakan adobe flash CS3 pada konsep induksi elektormagnetik. Media ini dikembangkan menggunakan desain penelitian Borg and Gall dengan penyederhanaan tahapan menjadi 7 tahapan yakni potensi dan masalah, pengumpulan data, desain produk, validasi desain, revisi produk, uji coba produk, serta analisis dan pelaporan.

Kualitas media pembelajaran fisika interkatif yang dikembangkan berdasarkan validasi ahli materi menunjukkan skor rata-rata 3,65 dengan kategori "Sangat Baik", validasi ahli media menunjukkan skor rata-rata 3,82 dengan kategori "Sangat Baik", dan penilaian guru mata pelajaran melalui angket respon guru menunjukkan skor rata-rata 3,88 dengan kategori "Sangat Baik". Hasil analisis respon tanggapan peserta didik menujukkan skor ratarata 3,26 dengan kategori "Sangat Setuju". Dari hasil tersebut menunjukkan bahwa media pembelajaran fisika interaktif yang dikembangkan layak digunakan sebagai media pembelajaran fisika. Selain itu, media pembelajaran fisika interaktif yang dikembangkan memiliki keefektifan yang diukur dari peningkatan hasil belajar peserta didik yang menunjukkan rata-rata nilai $\mathrm{N}$-gain sebesar 0,47 dengan kategori "Sedang".

\section{B. Saran}

Berdasarkan penelitian yang dilakukan, adapun saran peneliti dalam mengembangkan media pembelajaran adalah:

1. Mengingat hasil produk penelitian dan pengembangan media pembelajaran ini memiliki manfaat bagi pembelajaran, maka disarankan untuk peneliti selanjutnya dapat mengembangkan produk ini lebih luas ataupun pada konsep fisika yang lainnya.

2. Bagi guru kiranya dapat memanfaatkan keunggulan dari software adobe flash CS3 ataupun jenis lainnya yang berkaitan dengan media pembelajaran interaktif, sehingga 
dapat membuat proses pembelajaran lebih menarik lagi.

3. Bagi peneliti selanjutnya, disarankan menambahkan simulasi yang dapat memperkuat pemahaman peserta didik akan konsep yang diajarakan dan dapat membuat media pembelajaran yang dihasilkan lebih interaktif lagi.

\section{DAFTAR PUSTAKA}

[1] V.F.D. Priandana dan B.I.G.P. Asto "Pengembangan Media Pembelajaran Multimedia Interaktif Berbantuan Software Macromedia Flash Pada Kompetensi Dasar Menerapkan Macam-Macam Gerbang Dasar Rangkaian Logika Di SMK Negeri 2 Bojonegoro". Jurnal Pendidikan Teknik Elektro, vol. 04, no. 01, pp. 177-181. 2015.

[2] Haeruddin. Pengembangan Media Pembelajaran Berbasis Macromedia Flash Untuk Meningkatkan Pemahaman Konsep Fisika Siswa Kelas XI IPA SMA Negeri 7 Palu. Tesis pada Program Magister Pendidikan
Sains Universitas Tadulako Palu: tidak diterbitkan, 2014.

[3] E.R. Y ViajayaniRadiyono dan D.T. Rahardjo. "Pengembangan Media Pembelajaran Fisika Menggunakan Macromedia Flash Pro 8 Pada Pokok Bahasan Suhu dan Kalor. Jurnal Pendidikan Fisika. Vol. 1, No. 1, pp. 144-155, April. 2013.

[4] R. Fathiyati dan R.P. Utami. "Pengembangan Media Pembelajaran Biologi Berbasis Macromedia Flash Sebagai Sumber Belajar Bagi Siswa SMA/MA Kelas XI Semester 2 Materi Pokok Sistem Reproduksi Manusia". Jurnal Seminar Nasional IX Pendidikan Biologi FKIP UNS. Pp. 211-217, 2012.

[5] Sugiyono. Metode Penelitian Pendidikan : Pendekatan Kuantitatif, Kualitatif, dan R\&D. Bandung: Alfabeta, 2012.

[6] S. Arikunto. Prosedur Penelitian Pendekatan Suatu Praktik. Jakarta: Rineka Cipta, 2006.

[7] Widoyoko. Teknik Penyusunan Instrumen Penelitian. Yogyakarta: Pustaka Belajar, 2012.

[8] R. Hake. Interactive-Engagement vs Traditional Methods: A Six Thousand Student Survey of Mechanics Test Data for Introductory Physics Course. American Journal of Physics 66, no.1, pp. 64-74, 1998. 